\title{
Movement data and their application for assessing the current distribution and conservation needs of the endangered Saimaa ringed seal
}

\author{
Marja Niemi*, Miina Auttila, Markku Viljanen, Mervi Kunnasranta
}

University of Eastern Finland, Department of Biology, PO Box 111, 80101 Joensuu, Finland

\begin{abstract}
Bycatch mitigation is currently the most important issue for conservation of the Critically Endangered Saimaa ringed seal Phoca hispida saimensis found exclusively in Lake Saimaa, Finland. Two types of fishing restrictions have been established in order to reduce mortality: a ban on gillnet fishing during the most critical season (spring) to enhance pup survival and a yearround ban on the types of fishing gear most likely to cause seal mortality (e.g. certain specified fish traps, hooks baited with fish, strong-mesh gillnets, multifilament nets and trammel nets). The spatial and temporal coverage of these restrictions has not always been based entirely on the ecology and movements of the seals. The current distribution area of the population is not fully known, and this hampers the assessment of conservation needs. In this study, adult Saimaa ringed seals were tracked with GPS phone tags to estimate home ranges and movements. In addition, pup movement data from VHF telemetry studies were used to determine current breeding areas and nursing sites. The mean home ranges of both adults and pups were around $90 \mathrm{~km}^{2}$. The current distribution area of the seals covers about $70 \%$ of the surface area of Lake Saimaa $\left(4400 \mathrm{~km}^{2}\right)$, and the breeding area covers about $51 \%$. The current springtime fishing restriction covers $63 \%$ of the estimated distribution area, and the restriction on fishing gear types covers $55 \%$. This new information on the spatial ecology of Saimaa ringed seals should be used to improve efforts to conserve the species.
\end{abstract}

KEY WORDS: Saimaa ringed seal $\cdot$ Phoca hispida saimensis $\cdot$ Home range $\cdot$ Movement $\cdot$ Bycatch mitigation $\cdot$ Distribution $\cdot$ Telemetry $\cdot$ Seal-fishery interaction

\section{INTRODUCTION}

Incidental mortality in fishing gear (bycatch), especially gillnets, is a major threat to many marine mammal species and populations (Lewison et al. 2004, Read 2008, Reeves et al. 2013). The landlocked freshwater subspecies of the ringed seal Phoca hispida saimensis, which lives exclusively in Lake Saimaa, Finland, is under severe threat from bycatch, mainly in gillnets used for recreational fishing (Hyvärinen \& Sipilä 1984, Sipilä et al. 1990, Hyvärinen et al. 1999, Sipilä 2003). Recently, human disturbance and the negative effects of climate warming have come to be regarded as additional threats to Saimaa seals (Ministry of the Environment 2011). The current total population size is around 300, with only 50 to 60 pups born annually (Metsähallitus 2012, www.metsa.fi/ sivustot/metsa/fi/Luonnonsuojelu/Lajitjaluontotyypit/ Uhanalaisetelaimet/Saimaannorppa/Hyljekanta2012/ Sivut/default.aspx). The IUCN Red List and the Red List of Finnish species have both designated the Saimaa ringed seal as Critically Endangered, which means that it is facing an extremely high risk of extinction (Rassi et al. 2010, Kovacs et al. 2012). In addition, it is categorized as being in need of special spatial conservation management and strict protec- 
tion under the European Union's Habitats Directive (Council Directive 92/43/EEC, Annexes II and IV). The conservation needs of this endemic subspecies have also been incorporated into national laws and conservation programmes (Wilson et al. 2001, Ministry of the Environment 2011).

Time and area fishery closures have been implemented in a number of areas to reduce marine mammal bycatch (Murray et al. 2000, Reeves 2000). Fishing has been regulated to some extent in the main known breeding areas of the seals in Lake Saimaa since the 1980s, and this regulation was recently reinforced by government decrees (294/2011 and 295/2011) issued under the Fishing Act (286/1982) (Finnish legislation available at www.finlex.fi). Bycatch mitigation in Lake Saimaa consists mainly of time and area closures, i.e. a multi-annual, pre-determined seasonal ban on gillnet fishing enforced over the period from 15 April to 30 June (springtime fishing restriction, Government Decree 294/2011). The aim of this regulation is to reduce seal mortality, especially of juveniles. The protected area to which the ban applies has been significantly expanded relative to the first restrictions laid down in 1982, from $65 \mathrm{~km}^{2}$ (Sipilä 2003) to the present figure of $>2000 \mathrm{~km}^{2}$. In addition, the most dangerous (i.e. risk-prone in terms of seal bycatch) types of fishing gear (e.g. certain specified fish traps, hooks baited with fish, strong-mesh gillnets, multifilament nets and trammel nets) have been forbidden all year round since 1999 in the area presumed to be inhabited by the seals (gear-type restriction, Government Decree 295/2011). The present gear-type restriction covers a surface area of $1741 \mathrm{~km}^{2}$ in Lake Saimaa. To be effective, these time and area closures must be based on the spatial and temporal distribution of the seal population and on fishing activities, including patterns of bycatch events; all of this information depends on the assistance and cooperation of fishermen and on the availability of adequate ecological data (Murray et al. 2000).

Saimaa ringed seals give birth to single pups in subnivean snow lairs from mid-February to midMarch (Sipilä 2003), after which female/pup pair behaviour is typically concentrated in the vicinity of the lairs (Rautio et al. 2009). Ringed seals exhibit strong inter-annual breeding site fidelity (Sipilä 2003, Kelly et al. 2010, Valtonen et al. 2012), and the birth lair locations of Saimaa ringed seals are quite well established (Sipilä 2003). The pups are weaned in mid-May, and after that they disperse (Niemi et al. 2011). In recent years, the movement capabilities of weaned pups (Niemi et al. 2011) have been considered when deciding on the spatial coverage of springtime fishing restrictions. However, no attempt has been made to take the movement capabilities of seals of any age group into account when deciding which areas should be subject to year-round restriction of fishing gear types. Until now, decisions have been based simply on the presumed overall area of distribution of the seals (Wilson et al. 2001). This area does not even cover all of the known lair sites at present. In addition, the fishing gear-type restriction seems to concentrate on pelagic areas, which are thought to be significant for foraging, given the role of fish species such as vendace Coregonus albula and smelt Osmerus eperlanus in the seals' diet (Sipilä \& Hyvärinen 1998, Kunnasranta et al. 1999, Auvinen et al. 2005). A recent study has shown, however, that pups prefer shallow areas (Niemi et al. 2011), and there is a general lack of knowledge regarding the habitat and foraging preferences of adult seals. There is therefore an urgent need to study the spatial ecology of Saimaa ringed seals in order to evaluate the conservation decisions associated with fishing restrictions. Knowledge of the spatial ecology of the seals is also needed in order to mitigate the potential effects of human-induced disturbances through landuse zoning and to provide guidance on the use of off-road vehicles. Furthermore, socio-economic pressures have increased as a result of the implementation of conservation measures, especially fishing restrictions (Salmi et al. 2000, Tonder \& Jurvelius 2004, Bell et al. 2008), and better knowledge of seal behaviour is needed to justify the conservation decisions that have been taken and to reduce the level of conflict between policy-makers and local people.

The aims of this study were to determine the habitat use, home range size and movement patterns of Saimaa ringed seals, to provide data relevant to conservation, especially in relation to spatial fishing restrictions, and to produce practical information that would justify the regional conservation measures taken. Using integrated data from the movement patterns of pups and adults in relation to their known lair locations, we estimated the current distribution area, breeding area, nursing sites and potential distribution area of the seal population for the purposes of re-designing the protected areas and developing other conservation measures.

\section{MATERIALS AND METHODS}

Lake Saimaa, situated in south-eastern Finland $\left(61^{\circ} 05^{\prime}\right.$ to $62^{\circ} 36^{\prime} \mathrm{N}, 27^{\circ} 15^{\prime}$ to $30^{\circ} 00^{\prime} \mathrm{E}$ : Fig. 1 ), is a fragmented lake with numerous interconnected water 


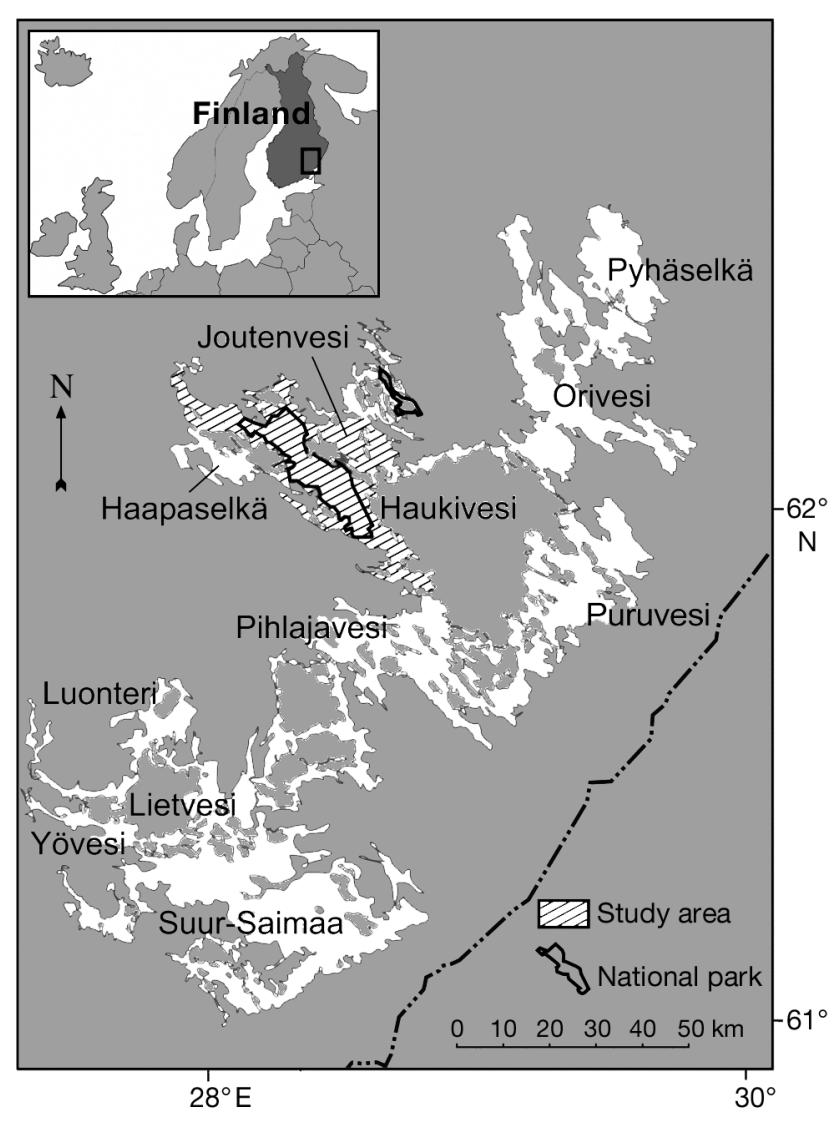

Fig. 1. Lake Saimaa showing its various water basins, national parks and the study areas

basins. Its surface area is $4400 \mathrm{~km}^{2}$, with $>14000 \mathrm{~km}$ of shoreline and $>13000$ islands (Kuusisto 1999). The lake is about $180 \mathrm{~km}$ in length and $140 \mathrm{~km}$ in width, with a mean depth of $12 \mathrm{~m}$ and a maximum depth of $85 \mathrm{~m}$. The lake is covered by ice for about 5 mo of the year, from the end of November to early May. This study was conducted from May 2007 to January 2012 in the Lake Haukivesi and Lake Joutenvesi basins (Fig. 1). Additional data on pup movements in the same study areas from the years 1995 and 2007 to 2010 (Niemi et al. 2011) were also used.

Nine free-ranging adult Saimaa ringed seals (Table 1) were tagged with GPS phone tags (Sea Mammal Research Unit, St. Andrews University, UK), with the location (fastloc/fastcat) interval set at 20 to 30 min and the GPS call interval at $12 \mathrm{~h}$. In addition, we used movement data obtained from 11 pups ( $n=2$ in the present study and $n=9$ from the study by Niemi et al. 2011) tagged with VHF radio tags (MM150 and MM-190, Advanced Telemetry Systems, weight ca. 20 to $50 \mathrm{~g}, 138 \mathrm{MHz}$ ).

The adult seals were captured in water at their haul-out sites during the moulting season in early summer using modified tangle nets (bar length: $150 \mathrm{~mm}$, height: $10 \mathrm{~m}$, length: $250 \mathrm{~m}$ ) which were set by surrounding a seal with motorboats while it was basking on the rocks on the shore of an island. The entangled seal was immediately pulled from the water and restrained manually. The pups were captured during the nursing season in early spring, as previously described by Niemi et al. (2011). All tags were attached to the seal's dorsal post-moult pelage with 2-component epoxy glue (Super Epoxy, $15 \mathrm{~min}$ ). For later identification, a uniquely numbered plastic roto tag (Dalton) was attached to the hind flipper of each seal. The tagged animals were released in the vicinity of their capture sites. Age class was determined upon capture on the basis of body length and mass. Permits for this work were obtained from the local environmental authorities and the Animal Experiment Board in Finland (ESAVI-2010-08380/ Ym-23).

Home range was estimated for each adult seal by the $100 \%$ local convex hull method $(\mathrm{LoCoH}$, also described originally as k-NNCH), which is a nonparametric kernel method generalizing the minimum convex polygon (MCP) based on local nearest-neighbour convex hulls (Getz \& Wilmers 2004, Getz et al. 2007). The method is especially suitable for a large set of location points such as GPS datasets. More precisely, we used the adaptive or a-LoCoH method, which is the most robust of the $\mathrm{LoCoH}$ methods and the least sensitive to changes in the value of the parameter a (Getz et al. 2007), which was set by following the 'rule of thumb' of taking the maximum distance between any 2 points in the individual's dataset. The latter was determined using Hawth's tool extension (Version 3.27; Beyer 2004) in ArcGIS 9.3 (ESRI 2008). The home range analyses were performed using the 'adehabitat' package (Version 1.8.3; Calenge 2006) for the R 2.13.2 statistical software (R Development Core Team 2011).

The nursing period and total home range were estimated for 7 ( $n=6$ from Niemi et al. 2011, $n=1$ in the present study) of a total of 11 pups ( $\mathrm{n}=9$ from Niemi et al. 2011, $\mathrm{n}=2$ in the present study). The nursing period home range was defined to include the locations recorded from tagging until mid-May, on average, and the total period home range as the locations from tagging to at least the end of the springtime fishing restriction (30 June). Both home range estimates were calculated by means of the MCP100\% (described in detail by Niemi et al. 2011). The home ranges presented here were determined using Hawth's tool extension (Version 3.27; Beyer 2004) in ArcGIS 9.3 (ESRI 2008). 
Table 1. Phoca hispida saimensis. Details of adult Saimaa ringed seals fitted with GPS phone tags, sizes of their home ranges (100\% local convex hull method) and maximum distances between observed locations. F: female; M: male; (-): no data available

\begin{tabular}{|c|c|c|c|c|c|c|c|c|c|}
\hline ID & Sex & $\begin{array}{l}\text { Mass } \\
(\mathrm{kg})\end{array}$ & $\begin{array}{l}\text { No. of } \\
\text { locations }\end{array}$ & $\begin{array}{l}\text { Mean no. of } \\
\text { locations d }{ }^{-1}\end{array}$ & $\begin{array}{l}\text { Min.-max. no. } \\
\text { of locations d }{ }^{-1}\end{array}$ & $\begin{array}{l}\text { Home range } \\
\qquad\left(\mathrm{km}^{2}\right)\end{array}$ & $\begin{array}{l}\text { Max. distance } \\
(\mathrm{km})\end{array}$ & $\begin{array}{c}\text { Study period } \\
\text { Start }\end{array}$ & $\begin{array}{l}\mathrm{dd} / \mathrm{mm} / \mathrm{yy}) \\
\text { End }\end{array}$ \\
\hline HE07 & $\mathrm{F}$ & 57 & 3003 & 16 & $0-34$ & 87.57 & 20.25 & 01/06/07 & 09/12/07 \\
\hline KJ07 & $\mathrm{M}$ & 52 & 4970 & 23 & $0-42$ & 137.05 & 24.74 & $25 / 05 / 07$ & $29 / 12 / 07$ \\
\hline TO07 & $\mathrm{M}$ & 55 & 3860 & 13 & $0-38$ & 113.73 & 26.42 & 03/06/09 & $28 / 03 / 10$ \\
\hline VI09 & $\mathrm{M}$ & 124 & 5035 & 25 & $5-43$ & 80.67 & 21.00 & $26 / 05 / 09$ & 11/12/09 \\
\hline TA10 & $\mathrm{M}$ & $\sim 65$ & 3 & - & - & - & - & $12 / 12 / 10$ & $26 / 12 / 10$ \\
\hline LI10 & $\mathrm{F}$ & 48 & 2000 & 36 & $18-56$ & 172.32 & 36.45 & $21 / 05 / 10$ & $15 / 07 / 10$ \\
\hline OL10 & $\mathrm{F}$ & 59 & 2793 & 9 & $0-38$ & 34.80 & 10.21 & $31 / 05 / 10$ & 02/04/11 \\
\hline OI10 & $\mathrm{M}$ & 57 & 0 & - & - & - & - & $27 / 05 / 10$ & $28 / 05 / 10$ \\
\hline ER11 & $\mathrm{M}$ & 66 & 3822 & 30 & $4-57$ & 20.19 & 7.63 & $20 / 05 / 11$ & $22 / 09 / 11$ \\
\hline Mean & & 65 & 2832 & 18 & & 92.3 & 21.0 & & \\
\hline Range & & $48-124$ & $0-5035$ & $9-36$ & & $20-172$ & $8-36$ & & \\
\hline
\end{tabular}

The current distribution area of the Saimaa ringed seal was estimated based on the mean home range size of the adults and known locations of haul-out lairs $(\mathrm{n}=4533)$ and birth lairs $(\mathrm{n}=614)$ in the years from 2000 to 2010 ( ${ }^{\circ}$ database of Metsähallitus 2012). The breeding area was estimated based on the mean total size of home ranges of the pups and known birth lair locations in the years from 2000 to $2010\left({ }^{\circledR}\right.$ database of Metsähallitus 2012). Furthermore, the nursing sites were estimated based on mean nursing season size of the home ranges of the pups and known birth lair locations in the years from 2000 to 2010

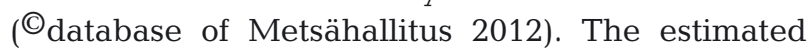
distribution and breeding areas were compared with the areas covered by the present year-round fishing gear-type restriction $\left({ }^{\circ}\right.$ database of Metsähallitus 2011) and the springtime fishing restriction (data of South Savo ELY Centre 2012) in order to identify unprotected regions.

Furthermore, the number of buildings ( ${ }^{\circ}$ National Land Survey of Finland 2012, data updated in 2010) included in the nursing sites and the minimum distances of the buildings from the birth lair locations were calculated in order to identify potential sources of human-induced disturbance in the most critical zone for seals during the breeding season. Habitat usage by adult seals was assessed by dividing the home range area into land areas, shallow water $(<6 \mathrm{~m}$, based on the international classification for inland waters) and deep water (>6 m).

\section{RESULTS}

Seven GPS phone tags on adult seals Phoca hispida saimensis (3 females and 4 males) provided sufficient location data for the analyses (Table 1). This is the first time that Saimaa ringed seal behaviour has been studied at a GPS level of accuracy with a high number of locations received per day (average: 18, range: 0 to 57; Table 1). Overall, the adult seals were tracked for periods ranging from 55 to $306 \mathrm{~d}$ (Table 1), in the open-water season. Complete records from early summer to the next spring were obtained from 2 seals. The maximum distance between any 2 location points in the individual data for adult seals averaged $21 \mathrm{~km}$ (range: 8 to $36 \mathrm{~km}$; Table 1). The individual values for the maximum distance between locations were used as the parameter $a$ in the homerange analyses. The locations of the adults were divided almost equally between shallow (45\%) and deep $(55 \%)$ areas in their home ranges.

The mean $( \pm \mathrm{SD})$ home range $(100 \% a-\mathrm{LoCoH})$ of the adult seals was $92.3 \pm 54 \mathrm{~km}^{2}$, ranging from 20 to $>172 \mathrm{~km}^{2}$ (Table 1). Due to the varying lengths of time for which the pups were studied, the total and nursing-period home ranges were estimated for different pups, yielding figures of $121.3 \mathrm{~km}^{2}$ for the total home range $(\mathrm{n}=1)$ and $0.13 \mathrm{~km}^{2}$ for the nursing home range $(n=1)$. Combining these results with the data of Niemi et al. (2011), we obtain figures of $93.9 \pm$ $69.4 \mathrm{~km}^{2}$ (mean $\pm \mathrm{SD}$ ) for the pups' total home range ( $\mathrm{n}=7$ ) and $1.97 \pm 2.36 \mathrm{~km}^{2}$ for the nursing-period home range $(\mathrm{n}=7)$.

The current spatial distribution of the Saimaa ringed seal, which was estimated on the basis of the mean home range of the adult animals $\left(92.3 \mathrm{~km}^{2}\right)$ in relation to all known lair locations in the years from 2000 to 2010, was $3093 \mathrm{~km}^{2}$ (land areas subtracted; Fig. 2). This encompasses about $70 \%$ of the surface area of the lake. In addition, the estimated breeding area (Fig. 3) based on the mean total home range of the pups $\left(93.9 \mathrm{~km}^{2}\right)$ and known birth lair locations in the years from 2000 to 2010 was $2244 \mathrm{~km}^{2}$ (land areas 


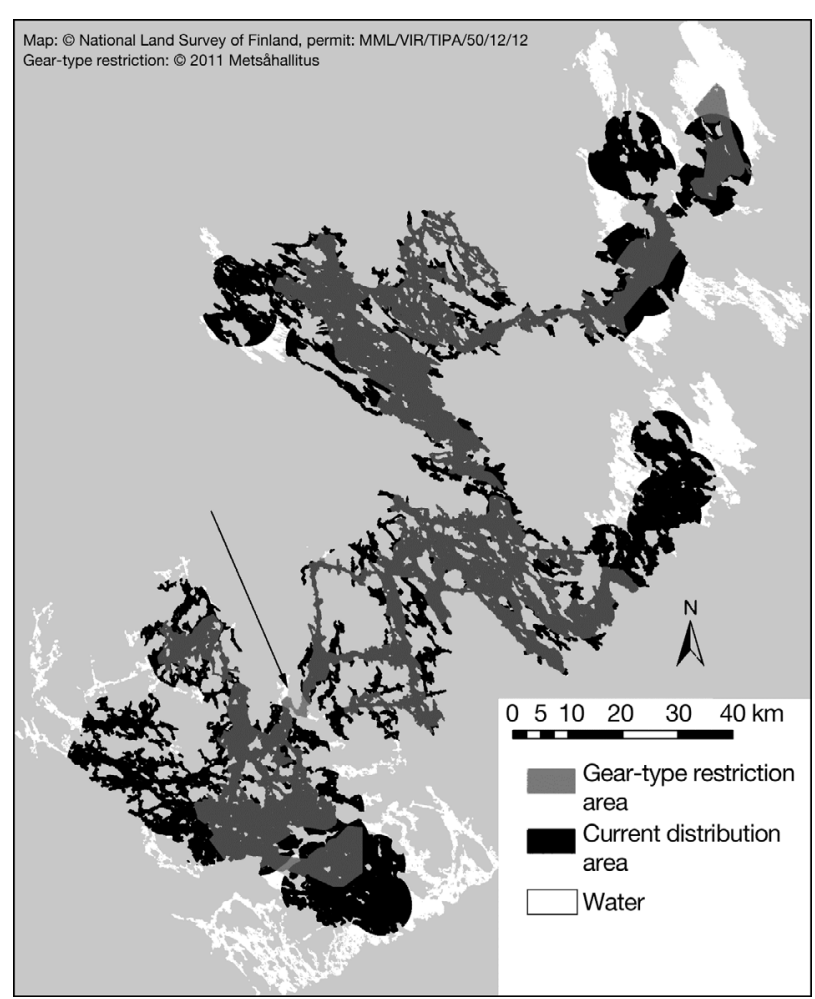

Fig. 2. Phoca hispida saimensis. Current distribution area (black) of the Saimaa ringed seal based on lair censuses and estimated home ranges of adults. The current year-round fishing gear-type restriction area is shown in dark grey. The arrow shows a 'gap' in the current distribution area between the water basins

subtracted). The fishing gear-type restriction area encompasses $55 \%$ of this current distribution area and $63 \%$ of the breeding area, whereas the springtime fishing restriction area encompasses $63 \%$ of the current distribution area and $83 \%$ of the current breeding area. The mean $( \pm \mathrm{SD})$ distance of the birth lair location from the nearest permanently inhabited building was $1.9 \pm 0.9 \mathrm{~km}$, ranging from 0.1 to $6.4 \mathrm{~km}$, and that from the nearest summer cottage $0.7 \pm$ $0.6 \mathrm{~km}$, ranging from 0.02 to $3.4 \mathrm{~km}$.

The total water area covered by the 614 identified nursing sites was $450 \mathrm{~km}^{2}$ (Fig. 4), given that a nursing site comprises the birth lair and a surrounding radius of $792 \mathrm{~m}$, based on the mean home range of pups during the nursing period $\left(1.97 \mathrm{~km}^{2}\right)$. Out of a total of 2753 buildings identified in the vicinity of 447 nursing sites (Fig. 4), 1608 were outbuildings, etc., 1077 were summer cottages and 68 were permanently occupied dwelling houses. Summer cottages occurred within 414 nursing sites, and dwelling houses, within 48 . The minimum distances of the birth lairs from the summer cottages within the nurs-

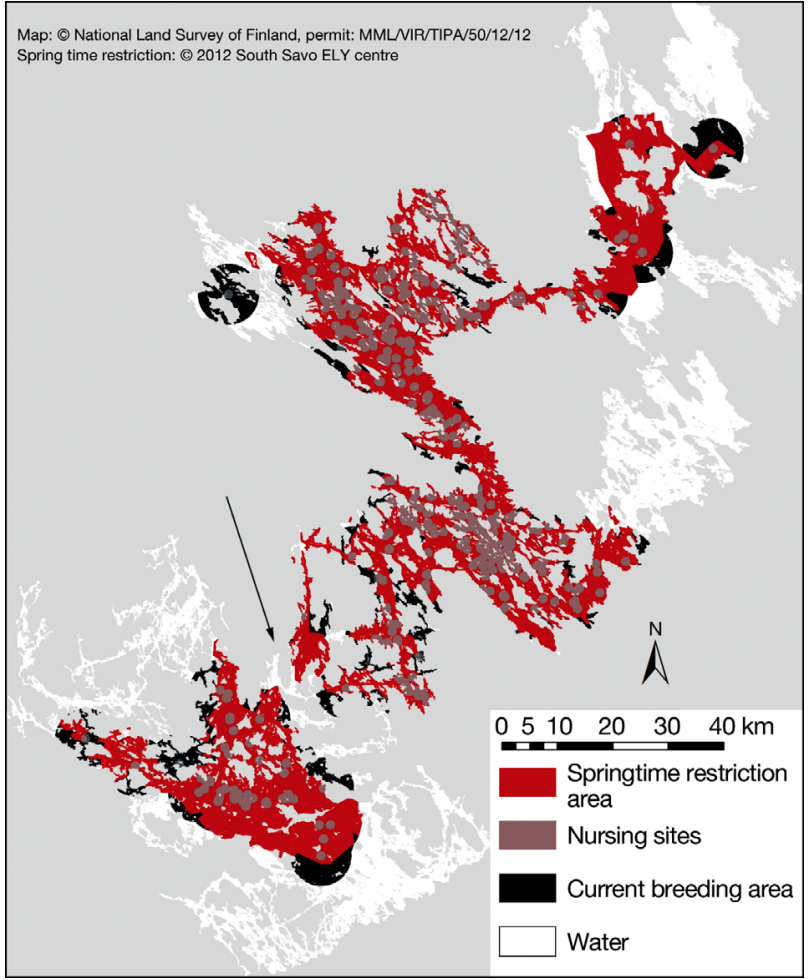

Fig. 3. Phoca hispida saimensis. Current breeding areas (black) and nursing sites (dark grey) of Saimaa ringed seals based on the birth lair censuses and estimated home ranges of pups (birth lairs have an $800 \mathrm{~m}$ buffer around them). The springtime fishing restriction area is shown in red. The arrow shows a 'gap' in the current breeding area between the water basins

ing sites $(0.4 \pm 0.2 \mathrm{~km})$ were shorter than the distances from the dwelling houses $(0.6 \pm 0.2 \mathrm{~km})$.

\section{DISCUSSION}

It is known that adult Saimaa ringed seals Phoca hispida saimensis exhibit a high degree of site fidelity and do not make long-distance migrations, factors which make this subspecies especially vulnerable to changes in its habitat (Hyvärinen et al. 1995, Kunnasranta 2001, Koskela et al. 2002, Kunnasranta et al. 2002). Regardless of the sedentary behaviour of these seals, their estimated current distribution area encompasses about $70 \%$ of the total surface area of Lake Saimaa. In addition, the potential distribution range may cover the entire lake, in view of the considerable movement capabilities of ringed seals (e.g. Heide-Jørgensen et al. 1992, Gjertz et al. 2000, Born et al. 2004, Freitas et al. 2008, Kelly et al. 2010, Niemi et al. 2011, present study). This conclusion is also 


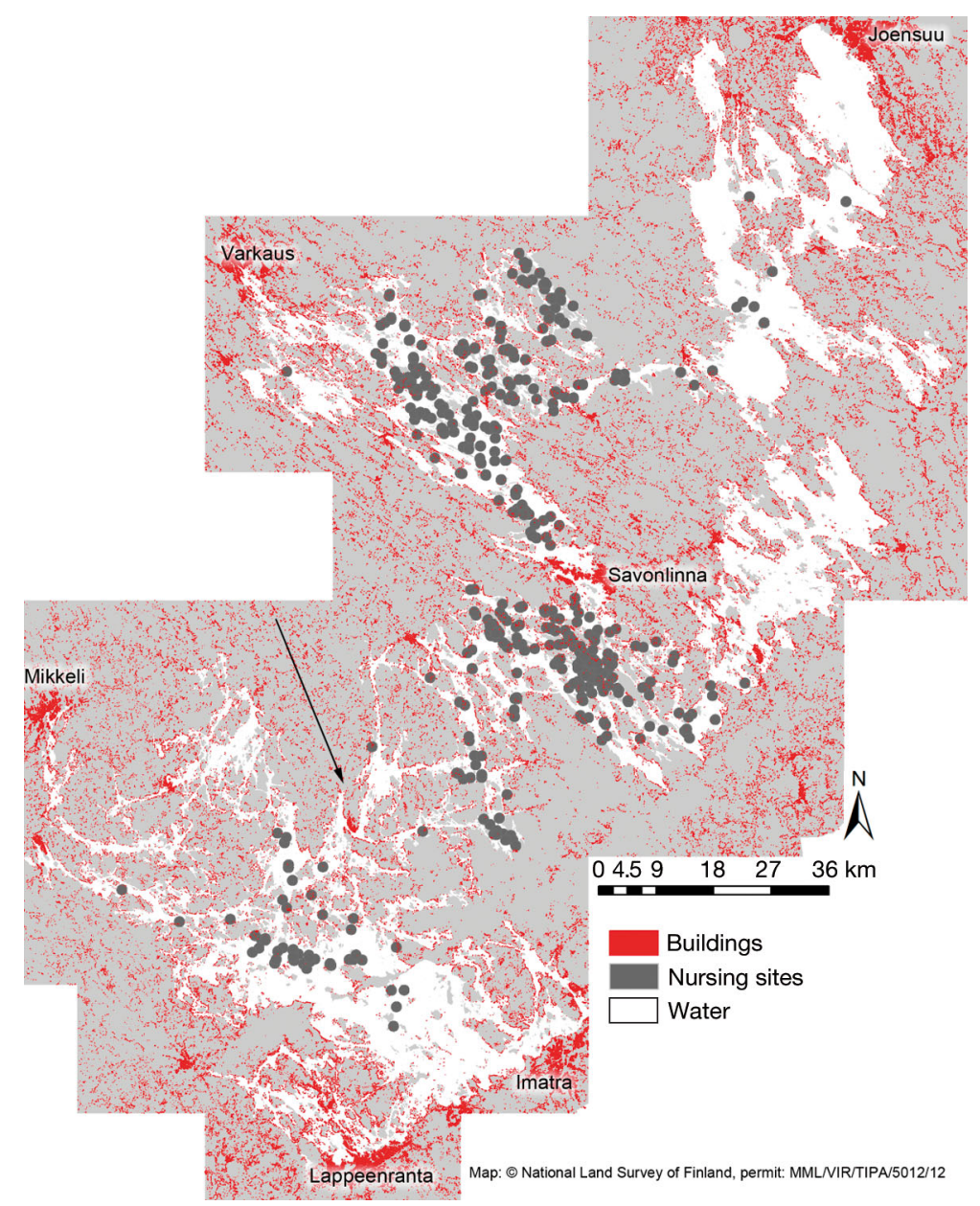

Fig. 4. Phoca hispida saimensis. Nursing sites (dark grey) of Saimaa ringed seals in relation to buildings (red) in the Lake Saimaa area. The nursing sites were established by creating $800 \mathrm{~m}$ buffers around the seals' birth lairs. The towns around Lake Saimaa are named. The arrow shows a 'gap' in the current distribution and breeding areas between the water basins (see Figs. 2 \& 3)

supported by observations of individual seals outside of the main distribution area during the open-water season ( ${ }^{\circledR}$ database of Metsähallitus 2012). Given the limited resources available and the variety of socioeconomic pressures that exist in the region, the main immediate conservation measures should focus on the current areas of the seals' distribution while bearing in mind that the seals are also capable of recolonizing previously occupied areas. The Puruvesi basin (Fig. 1), for example, has not been used by wintering seals since the 1950s (Hyvärinen et al. 1999), but individual seals have been observed in the area in recent annual counts and an adult female was entangled in a gillnet there in 2009 (database of Metsähallitus 2011). In addition, only a few haul-out lairs had been found in the Haapaselkä area (Fig. 1) in the 2000s before the first birth lair was identified there in 2010.

The estimated current distribution and breeding areas both point to the possibility of separate subpopulations, judging by the gap in occurrence northeast of the Lietvesi basin (arrows in Figs. 2 to 4 ). This possibility is supported by a recent genetic study of mitochondrial DNA, which indicated that the seals in southern Saimaa differ significantly from those in the other water basins (Valtonen et al. 2012), suggesting some degree of structure within the Saimaa ringed seal population. Restricted gene flow within the lake would increase the risk of extinction of the subspecies (Palo et al. 2003, Valtonen et al. 2012). It is therefore essential that the apparent 'distribution gap' is included in the fishing restriction areas to provide an ecological corridor enabling the exchange of individuals between the breeding areas and to enhance gene flow.

Bycatch mitigation is considered the most urgent conservation need for the Saimaa ringed seal population (Kokko et al. 1998, Sipilä 2003, Ministry of the Environment 2011). Up to 3 adult seals died annually in dangerous fishing gear from 2000 to 2010, in spite of the year-round fishing gear-type restriction (Table 2). In general, increased adult mortality has the greatest effect on the rate of population growth and can increase the risk of extinction of an endangered population (Goodman 1981, Baker \& Thompson 2007). For example, the negative impact on the population of the loss of an adult female grey seal Halichoerus grypus is more than double that caused by the loss of a pup (Harding et al. 2007). The loss of adults is a very serious problem for a small population like that of the Saimaa ringed seal. We therefore recommend that the minimum requirement for spatial coverage of the fishing gear-type restriction should be the entire distribution area as defined here, whereas the current restriction covers only somewhat more than half (55\%) of this area (Fig. 2). Furthermore, the shallows, mainly near shore, should be included in the fishing restrictions much more extensively than they are at present. The reason for this is that, in addition to vendace and smelt, littoral fish species such as ruffe Gymnocephalus cernuus, perch Perca fluviatilis and roach Rutilus rutilus make 
Table 2. Phoca hispida saimensis. Numbers of Saimaa ringed seals bycaught in fishing gear during the period from 2000 to 2010 (database of Metsähallitus 2011). See 'Introduction' for definitions of regular and 'dangerous' fishing gear

\begin{tabular}{|c|c|c|c|c|c|c|}
\hline & \multicolumn{2}{|c|}{$\begin{array}{l}\text { Observed regular } \\
\text { fishing gear }\end{array}$} & \multicolumn{2}{|c|}{$\begin{array}{l}\text { Observed 'dangerous' } \\
\text { fishing gear }\end{array}$} & \multirow{2}{*}{$\begin{array}{l}\text { Type of fishing } \\
\text { gear or seal } \\
\text { age unknown }\end{array}$} & \multirow[t]{2}{*}{ Total } \\
\hline & Pups & $>1 \mathrm{yr}$ & Pups & $>1 \mathrm{yr}$ & & \\
\hline 2000 & 0 & 2 & 0 & 1 & $3^{\mathrm{a}}$ & 6 \\
\hline 2001 & 1 & 0 & 1 & 0 & 2 & 4 \\
\hline 2002 & 3 & 0 & 3 & 1 & 1 & 8 \\
\hline 2003 & 1 & 1 & 4 & 1 & $1^{\mathrm{a}}$ & 8 \\
\hline 2004 & 1 & 2 & 1 & 1 & 1 & 6 \\
\hline 2005 & 3 & 0 & 1 & 0 & 1 & 5 \\
\hline 2006 & 3 & 1 & 0 & 2 & 0 & 6 \\
\hline 2007 & 2 & 1 & 2 & 0 & 1 & 6 \\
\hline 2008 & 3 & 0 & 1 & 0 & 1 & 5 \\
\hline 2009 & 2 & 0 & 0 & 3 & 1 & 6 \\
\hline 2010 & 1 & 1 & 2 & 0 & $1^{\mathrm{a}}$ & 5 \\
\hline Total & 20 & 8 & 15 & 9 & 13 & 65 \\
\hline
\end{tabular}

up an important part of the diet of Saimaa ringed seals (Kunnasranta et al. 1999). Among the main prey items of the seals, vendace are under the greatest pressure from subsistence and commercial fishing (Finnish Game and Fisheries Research Institute 2010, 2011). Despite the relatively intense fishing that occurs in Lake Saimaa, it has been suggested that there is no competition between fishing and seals in Lake Saimaa (Auvinen et al. 2005).

In view of the movement capabilities of dispersing pups (Niemi et al. 2011, present study) and the high bycatch mortality of recently weaned pups (Sipilä 2003, Niemi et al. 2011), we suggest that conservation activities targeted at the seals' breeding habitat should cover not only the birth lairs and their surroundings but also potential dispersal areas. It was for this reason that in this study we estimated the main breeding area of the Saimaa ringed seal based on the mean home range of the weaned pups in relation to the known birth lair locations. The current springtime fishing restriction areas cover $>83 \%$ of the main breeding area as estimated here $\left(2244 \mathrm{~km}^{2}\right.$; Fig. 3). Although the restriction area has been extended in the last few years, a recent study (Niemi et al. 2011) has indicated that temporal coverage may be inadequate. Over half of the seals known to have become entangled in less dangerous types of fishing gear have been found after or before the springtime gillnet ban comes into effect $\left({ }^{\circ}\right.$ database of Metsähallitus 2011). We therefore suggest that the springtime fishing restriction should be reviewed and made temporally more comprehensive in order to achieve the short-term goal of 400 living seals by the year 2025, a figure which is specified in the Saimaa ringed seal conservation plan as the minimum viable population size (Ministry of the Environment 2011). In addition, new sealsafe fishing gear and methods should be developed, and the supervision of fishing should be intensified.

The figure of around $90 \mathrm{~km}^{2}$ for the mean home range of both adults and pups in this study, in spite of earlier suggestions that young Saimaa ringed seals move over larger areas than adults (Kunnasranta 2001, Niemi et al. 2011), could be explained by methodological differences: adults were studied by GPS tracking and pups by VHF telemetry. The less intensive VHF monitoring may miss significant animal movements so that the estimated home range is smaller than the corresponding GPS estimate (e.g. Kochanny et al. 2009). In the present study all the locations of the seals were taken into account for conservation purposes (100\% of the estimates). The home ranges determined by GPS with large numbers of location points are thought to be consistently larger and more accurate than the estimates obtained using traditional radiotelemetry (Tomkiewicz et al. 2010). It is therefore possible that future studies using GPS tracking will provide even larger home range estimates for pups, which may have a further effect on the determination of the seals' current distribution and breeding areas.

Human presence and activity is quite intense in Lake Saimaa on account of the 60000 summer cottages (Ministry of the Environment 2011) and 6 towns (with a minimum of $>20000$ inhabitants) in the region (Fig. 4). Saimaa ringed seals are thought to be most sensitive to disturbance during the winter breeding season (Sipilä 2003), and it is possible that the mild winters brought about by climate change will intensify the negative effects of disturbance. Various conservation programmes and the efforts of 2 national parks (Fig. 1) have been devoted to the protection of essential seal breeding areas (Sipilä 2003). Although the seals' birth lair locations themselves are supposed to be protected by landuse planning and regulation (Wilson et al. 2001, Sipilä 2003, Ministry of the Environment 2011), no means of identifying the minimum critical spatial coverage of the protection zone around the lairs 
has yet been established. It is for this reason that we have used the data from Niemi et al. (2011) as well as that gathered in this study to identify the most critical spots ('hotspots') within the main breeding area (nursing sites; Fig. 4) that should be subject to the strictest possible regulations as far as fishing, land-use and off-road vehicle activities are concerned. We suggest that the minimum buffer zone around known birth lairs should be $800 \mathrm{~m}$, the mean radius of the pups' home range during the nursing period. The present fishing gear type and springtime fishing restrictions encompass this area relatively well, with a coverage of $>97 \%$, but the mean minimum distance from the birth lair to a dwelling house is $2 \mathrm{~km}$ and that to a summer cottage $<1 \mathrm{~km}$. In previous work carried out in the 1980s (see Sipilä 1990), the nearest building was about $3 \mathrm{~km}$ away from the birth lair. The annual increase in the number of summer cottages in the Lake Saimaa area is in the range of 300 to 400 (Ministry of the Environment 2011). In the present study, $6 \%$ of all buildings found inside the current nursing sites were dwelling houses, and $39 \%$ were summer cottages. There is a growing tendency, however, for summer cottages to be converted for year-round occupation (Tonder 2005, Ministry of the Environment 2011) and this is very likely to lead to increased disturbance during breeding and nursing periods. Therefore, new (or newly discovered) birth lair locations should be brought immediately within the definition of nursing sites and placed under the strictest protection in terms of land-use planning.

Scientific knowledge of the basic biology and ecology of marine mammals is essential for the design and implementation of conservation measures (Davidson et al. 2012). Effective conservation of endangered species requires an understanding of how they are distributed spatially and how the potential risks to the population are distributed spatially (Hooker \& Gerber 2004, Ward et al. 2012). An optimally protected area would encompass the population's year-round distribution area (Reeves 2000). Understanding the spatial usage patterns of Saimaa ringed seals is fundamental to monitoring and conservation. Updated knowledge of the population's current distribution should be used to identify critical areas for long-term survival, and such information should guide future decision-making.

The work presented in this paper has 2 major implications for the conservation of Saimaa ringed seals. First, the area to which the fishing gear-type restriction applies should be based on the spatial ecology of the seals and cover at least their current distribution area as determined from movement data. Second, the minimum protection provided for birth lair sites should cover at least the home range of the pups during the nursing period, i.e. the nursing sites (including a $800 \mathrm{~m}$ buffer around each birth lair) should be under the strictest protection with regard to fishing, land use and off-road traffic. In addition, we emphasise our concern over the restriction of gillnet fishing in spring. Although the current coverage of the restriction seems to be spatially tolerable in relation to the pups' movement capabilities, its temporal coverage appears to be inadequate.

Acknowledgements. We thank our field assistants, especially T. Laitinen, J. Ketonen, A. Kirjavainen, M. Koivuniemi, M. Margaritis, J. Taskinen, M. Uimonen, E. Uimonen, M. Vehmas, J. Vierimaa and S. Oksanen, and also A. Rautio and M. Valtonen for commenting on the manuscript. We also thank all the other staff members who have helped us in this research, especially K. Kyyrönen. In addition, we acknowledge the technical advice received from the Sea Mammal Research Unit staff and the productive co-operation we have enjoyed with T. Sipilä and T. Kokkonen of Metsähallitus and J. Tiitinen and V. Väisänen of the South Savo ELY Centre. We are grateful to $\mathrm{H}$. Huuskonen and $\mathrm{M}$. Sokka for their valuable comments on the manuscript, and to H. Shiels and M. Hicks for revising the English language of the manuscript. This project was supported financially by the Finnish Ministry of the Environment, the Raija and Ossi Tuuliainen Foundation, WWF Finland and the Finnish Ministry of Agriculture and Forestry. Additional support was provided by Fortum PLC and the North Karelia Regional Fund of the Finnish Cultural Foundation (MN). This manuscript has been greatly improved as a result of comments from 2 anonymous reviewers and Responsible Editor R. Reeves. This paper is part of a series of contributions to the national action plan and conservation strategy for the Saimaa ringed seal.

\section{LITERATURE CITED}

Auvinen H, Jurvelius J, Koskela J, Sipilä T (2005) Comparative use of vendace by humans and Saimaa ringed seal in Lake Pihlajavesi, Finland. Biol Conserv 125:381-389

Baker JD, Thompson PM (2007) Temporal and spatial variation in age-specific survival rates of a long-lived mammal, the Hawaiian monk seal. Proc R Soc Lond B Biol Sci 274:407-415

Bell S, Hampshire K, Tonder M (2008) Person, place and knowledge in the conservation of the Saimaa ringed seal. Soc Nat Resour 21:277-293

Beyer HL (2004) Hawth's analysis tools for ArcGIS. Available at: www.spatialecology.com/htools (accessed 5 October 2011)

Born EW, Teilmann J, Acquarone M, Riget FF (2004) Habitat use of ringed seals (Phoca hispida) in the North Water area (North Baffin Bay). Arctic 57:129-142

> Calenge C (2006) The package adehabitat for the R software: a tool for the analysis of space and habitat use by animals. Ecol Model 197:516-519 
Davidson AD, Boyer AG, Kim H, Pompa-Mansilla S and others (2012) Drivers and hotspots of extinction risk in marine mammals. Proc Natl Acad Sci USA 109:3395-3400

ESRI (Environmental Systems Research Institute) (2008) ArcGIS Desktop 9.3. ESRI, Redlands, CA

Finnish Game and Fisheries Research Institute (2010) Commercial inland fishery 2008. Riista-ja kalatalous - Tilastoja 1/2010. Official Statistics of Finland-Agriculture, Forestry and Fishery. Finnish Game and Fisheries Research Institute, Helsinki

Finnish Game and Fisheries Research Institute (2011) Recreational Fishing 2010. Riista-ja kalatalous-Tilastoja 7/2011. Official Statistics of Finland-Agriculture, Forestry and Fishery. Finnish Game and Fisheries Research Institute, Helsinki

Freitas C, Kovacs KM, Ims RA, Fedak MA, Lydersen C (2008) Ringed seal post-moulting movement tactics and habitat selection. Oecologia 155:193-204

Getz WM, Wilmers CC (2004) A local nearest-neighbor convex-hull construction of home ranges and utilization distributions. Ecography 27:489-505

Getz WM, Fortmann-Roe S, Cross PC, Lyons AJ, Ryan SJ, Wilmers CC (2007) LoCoH: nonparametric kernel methods for constructing home ranges and utilization distributions. PLoS ONE 2:e207

Gjertz I, Kovacs KM, Lydersen C, Wiig Ø (2000) Movements and diving of adult ringed seals (Phoca hispida) in Svalbard. Polar Biol 23:651-656

Goodman D (1981) Life history analysis of large mammals. In: Fowler CW, Smith TD (eds) Dynamics of large mammal populations. Wiley, New York, NY, p 415-436

Harding KC, Härkönen T, Helander B, Karlsson O (2007) Status of Baltic grey seals: population assessment and extinction risk. In: Haug $\mathrm{T}$, Hammill $\mathrm{M}$, Ólafsdóttir D (eds) Grey seals in the North Atlantic and the Baltic. NAMMCO, Tromsø, p 33-56

- Heide-Jørgensen MP, Stewart BS, Leatherwood S (1992) Satellite tracking of ringed seals Phoca hispida off northwest Greenland. Ecography 15:56-61

> Hooker SK, Gerber LR (2004) Marine reserves as a tool for ecosystem-based management: the potential importance of megafauna. Bioscience 54:27-39

> Hyvärinen H, Sipilä T (1984) Heavy metals and high pup mortality in the Saimaa ringed seal population in eastern Finland. Mar Pollut Bull 15:335-337

> Hyvärinen H, Hämäläinen E, Kunnasranta M (1995) Diving behavior of the Saimaa ringed seal (Phoca hispida saimensis Nordq.). Mar Mamm Sci 11:324-334

Hyvärinen H, Sipilä T, Koskela J, Kunnasranta M (1999) The Saimaa ringed seal. In: Kuusisto E (ed) Saimaa, a living lake. Tammi, Helsinki, p 126-136

Kelly BP, Badajos OH, Kunnasranta M, Moran JR, MartinezBakker M, Wartzok D, Boveng P (2010) Seasonal home ranges and fidelity to breeding sites among ringed seals. Polar Biol 33:1095-1109

> Kochanny CO, Delgiudice GD, Fieberg J (2009) Comparing global positioning system and very high frequency telemetry home ranges of white-tailed deer. J Wildl Manag 73:779-787

Kokko H, Lindström J, Ranta E, Sipilä T, Koskela J (1998) Estimating the demographic effective population size of the Saimaa ringed seal (Phoca hispida saimensis Nordq.). Anim Conserv 1:47-54

Koskela JT, Kunnasranta M, Hämäläinen E, Hyvärinen $\mathrm{H}$ (2002) Movements and use of haul-out sites of radio-tagged
Saimaa ringed seal (Phoca hispida saimensis Nordq.) during the open-water season. Ann Zool Fenn 39:59-67

> Kovacs KM, Aguilar A, Aurioles D, Burkanov V and others (2012) Global threats to pinnipeds. Mar Mamm Sci 28: 414-436

Kunnasranta M (2001) Behavioural biology of two ringed seal (Phoca hispida) subspecies in the large European lakes Saimaa and Ladoga. PhD dissertation, University of Joensuu, Joensuu

Kunnasranta M, Hyvärinen H, Sipilä T, Koskela JT (1999) The diet of the Saimaa ringed seal (Phoca hispida saimensis). Acta Theriol (Warsz) 44:443-450

Kunnasranta M, Hyvärinen H, Häkkinen J, Koskela JT (2002) Dive types and circadian behaviour patterns of Saimaa ringed seals Phoca hispida saimensis during the open-water season. Acta Theriol (Warsz) 47: $63-72$

Kuusisto E (1999) Basin and balances. In: Kuusisto E (ed) Saimaa, a living lake. Tammi, Helsinki, p 21-39

> Lewison RL, Crowder LB, Read AJ, Freeman SA (2004) Understanding impacts of fisheries bycatch on marine megafauna. Trends Ecol Evol 19:598-604

Ministry of the Environment (2011) Saimaannorpan suojelun strategia ja toimenpidesuunnitelma (Conservation strategy and action plan of Saimaa ringed seal). Ministry of the Environment, Helsinki (in Finnish)

Murray KT, Read AJ, Solow AR (2000) The use of time/area closures to reduce bycatches of harbor porpoises: lessons from the Gulf of Maine sink gillnet fishery. J Cetacean Res Manag 2:135-141

Niemi M, Auttila M, Viljanen M, Kunnasranta M (2011) Home range, survival and dispersal of endangered Saimaa ringed seal pups: implications for conservation. Mar Mamm Sci, doi:10.1111/j.1748-7692.2011.00521.x

> Palo JU, Hyvärinen H, Helle E, Mäkinen HS, Väinölä R (2003) Postglacial loss of microsatellite variation in the landlocked Lake Saimaa ringed seal. Conserv Genet 4: 117-128

R Development Core Team (2011) R: a language and environment for statistical computing. $\mathrm{R}$ Foundation for Statistical Computing, Vienna. Available at: www.Rproject.org/ (accessed 13 October 2011)

Rassi P, Hyvärinen E, Juslén A, Mannerkoski I (2010) The 2010 Red List of Finnish species. Ministry of the Environment \& Finnish Environment Institute, Helsinki

Rautio A, Niemi M, Kunnasranta M, Holopainen IJ, Hyvärinen H (2009) Vocal repertoire of the Saimaa ringed seal (Phoca hispida saimensis) during the breeding season. Mar Mamm Sci 25:920-930

Read AJ (2008) The looming crisis: interactions between marine mammals and fisheries. J Mamm 89:541-548

Reeves RR (2000) The value of sanctuaries, parks and reserves (protected areas) as tools for conserving marine mammals. Final report to the marine mammal commission, Contract Number T74465385. Marine Mammal Commission, Bethesda, MD

Reeves RR, McClellan K, Werner TB (2013) Marine mammal bycatch in gillnet and other entangling net fisheries, 1990-2011. Endang Species Res, doi:10.3354/esr00481

Salmi P, Auvinen H, Jurvelius J (2000) Finnish lake fisheries and conservation of biodiversity: coexistence or conflict? Fish Manag Ecol 7:127-138

Sipilä T (1990) Lair structure and breeding habitat of the Saimaa ringed seal (Phoca hispida saimensis Nordq.) in Finland. Finnish Game Res 47:11-20 
Sipilä T (2003) Conservation biology of Saimaa ringed seal (Phoca hispida saimensis) with reference to other European seal populations. $\mathrm{PhD}$ dissertation, University of Helsinki, Helsinki

Sipilä T, Hyvärinen H (1998) Status and biology of Saimaa (Phoca hispida saimensis) and Ladoga (Phoca hispida ladogensis) ringed seals. In: Heide-Jørgensen MP, Lydersen C (eds) Ringed seals in the North Atlantic. NAMMCO, Tromsø, p 83-99

Sipilä T, Helle E, Hyvärinen H (1990) Distribution, population size and reproductivity of the Saimaa ringed seal (Phoca hispida saimensis Nordq.) in Finland, 1980-84. Finnish Game Res 47:3-10

Tomkiewicz SM, Fuller MR, Kie JG, Bates KK (2010) Global positioning system and associated technologies in animal behaviour and ecological research. Philos Trans R Soc Lond B Biol Sci 365:2163-2176

Editorial responsibility: Randall Reeves,

Hudson, Quebec, Canada
Tonder M (2005) Anatomy of an environmental conflict in a case of the conservation of the Saimaa ringed seal. PhD dissertation, University of Joensuu, Joensuu

> Tonder M, Jurvelius J (2004) Attitudes towards fishery and conservation of the Saimaa ringed seal in Lake Pihlajavesi, Finland. Environ Conserv 31:122-129

> Valtonen M, Palo JU, Ruokonen M, Kunnasranta M, Nyman $\mathrm{T}$ (2012) Spatial and temporal variation in genetic diversity of an endangered freshwater seal. Conserv Genet 13:1231-1245

Ward EJ, Levin PS, Lance MM, Jeffries SJ, Acevedo-Gutiérrez A (2012) Integrating diet and movement data to identify hot spots of predation risk and areas of conservation concern for endangered species. Conserv Lett 5:37-47

Wilson SC, Mo G, Sipilä T (2001) Legal protection for seals in small populations in European Community and Mediterranean coastal waters. Mammalia 65:335-348

Submitted: June 1, 2012; Accepted: October 2, 2012

Proofs received from author(s): December 4, 2012 